\title{
CYBER GOVERNMENT PUBLIC RELATIONS MANAGEMENT IN STRENGTHENING THE IMAGE OF THE INFORMATION TECHNOLOGY BOARD AND NATIONAL COMMUNICATION (WANTIKNAS)
}

\author{
Desy Septiyani* \\ Communication Science of Postgraduate Program \\ Universitas Prof. Dr. Moestopo (Beragama) \\ Yunita Sari \\ Communication Science of Postgraduate Program \\ Universitas Prof. Dr. Moestopo (Beragama) \\ *Correspondence: desysep2016@gmail.com
}

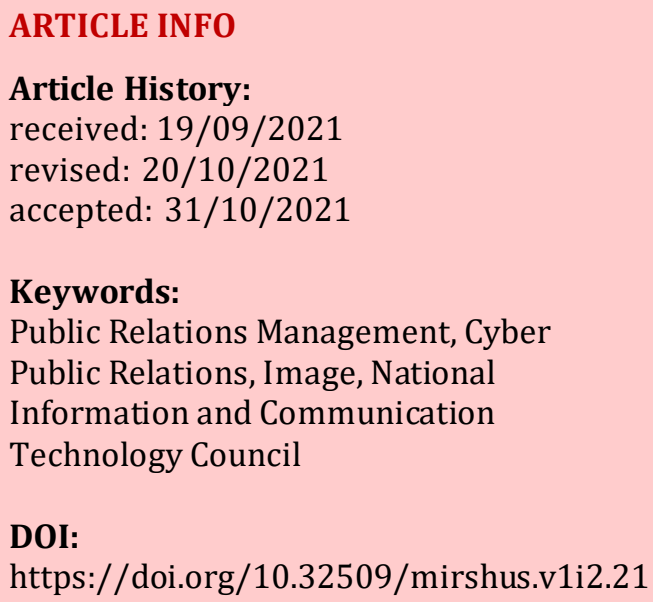

DOI:

https://doi.org/10.32509/mirshus.v1i2.21

\begin{abstract}
This studyaims: to determine the implementation of cyber Public Relations Wantiknas in strengthening the organization's image, and to determine the role and function of optimal cyber Public Relations management. The theory used is communication management theory Public Relations, Cyber Public Relations, two-way symmetrical communication, computer mediated communication theory, and image theory. The research method used is a case study. The results of the study show that WANTIKNAS has not implemented PR's management optimally which has an impact on the lack of management of cyber public relations, besides that limited human resources and not positioned in a strategic role in WANTIKNAS's internal become obstacles to the implementation of $P R$ 's activities in the delivery of information.
\end{abstract}

\section{INTRODUCTION}

The era of information disclosure and technological advances has made people more critical and brought about rapid and dynamic changes. This encourages organizations within the government, both ministries or non-ministerial government agencies, to local governments to accommodate and anticipate the public's desire to obtain information. Government Public Relations is a public relations agency or public relations practitioner that performs a management function in the field of information and communication that is persuasive, effective, and efficient, to create a harmonious relationship with the public through various PR's means in order to create a positive image and reputation, as 
well as to promote public relations. promote government policies and programs. Introduction

The era of information disclosure and technological advances has made people more critical and brought about rapid and dynamic changes. This encourages organizations within the government, both ministries or non-ministerial government agencies, to local governments to accommodate and anticipate the public's desire to obtain information. Government Public Relations is a public relations agency or public relations practitioner that performs a management function in the field of information and communication that is persuasive, effective, and efficient, to create a harmonious relationship with the public through various PR's means in order to create a positive image and reputation, as well as to promote public relations. promote government policies and programs.

The National Information and Communication Technology Council (WANTIKNAS) is one of the institutions that focuses on the field of Communication Information Technology, by implementing public interaction and communication with the public through digital media by utilizing social media Instagram, Facebook, YouTube, to the use of websites as official pages that describe organizational identity. So it is important for organizations to implement Cyber Public Relations well in building a corporate image. However, on the other hand, it can be a threat if it is not managed properly.

Cyber Public Relations is the activity of a Public Relations (PR's) who uses Cyber World (cyber world) in establishing cooperation. The use of cyber PR's becomes very effective, especially when there is a communication crisis, identifying problems, interactive management and communication. The number of digital platforms in Public Relations activities makes Cyber Public Relations management a must to be able to manage and strategize digital messages on all platforms used to have an impact on strengthening the organization's image. Based on the description above, this study aims to: determine the implementation of cyber Public Relations Wantiknas in strengthening the organization's image, and to determine the role and function of optimal cyber Public Relations management.

Previous research that forms the basis of this research is a similar research with the title PUBLIC RELATIONS MANAGEMENT IN IMPROVEMENT EFFORT SCHOOL IMAGE (CASE STUDY AT AL HIKMAH SMP SURABAYA) The purpose of this study was to determine and describe , among others, (1) public relations planning in improving imaging junior high school in $\mathrm{Al}$ Hikmah Surabaya. (2) The implementation of public relations in order to improve imaging in junior high school Al Hikmah Surabaya. (3) Evaluation of public relations in order to improve imaging in junior high school Al Hikmah Surabaya. (4) Efforts made in efforts to improve community relations in SMP Al Hikmah Surabaya. This study used a qualitative research approach with a case study research design. Data collection techniques were used: (1) Interviews (2) Observation (3) Documentation Studies. Analysis using (1) Data reduction (2) Presentation of data (3) Verification of the data or conclusions. To ensure the validity of data that is (1) Credibility (2) Transferability (3) dependability (4) Confirmability. (Harini, 2014)

The results showed that. First, public relations planning in improving imaging in junior high school Al Hikmah Surabaya involving all school administrators with an agenda all public relations activities as well as good planning and detailed program through annual meetings. Second, the implementation of public relations in SMP Al Hikmah Surabaya implemented according to plan which tasks publicist informs all 
activities at the school to be known to the public. Third, the evaluation of public relations in SMP Al Hikmah Surabaya performed according to standard school services, an evaluation conducted by external parties and internal party school. Fourth, efforts are made in improving community relations in SMP Al Hikmah Surabaya with increased giving of information to the public, update information through the means of information held by the school such as school magazines, school websites and the media means information or other information.

Public Relations (PR) first developed in America starting around the 1900s which was pioneered by Ivy Lee with "The Declaration of Principles" which is considered "the Father of Public Relations" because of its declaration of principles. The history of the development of Public Relations according to Ivy Lee as initial understanding of the development of public relations in Indonesia, because this concept is related to the position in top management and public relations has full authority in disseminating all fact-based information to the public.

Public Relations, Effendy (2006), classified public relations into two, namely the central government public relations and local government public relations. The classification made by Sam Black in Effendy (2006), looks more at the context of the organization and working mechanism of the central government public relations and local government public relations. According to him, they have the same task, although the scope is different.

Government Public Relations (GPR's) is a priority program to ensure the public knows what the government is doing and participate in development. The implementation of GPR is carried out in accordance with Presidential Instruction Number 9 of 2015 concerning the
Management of Public Communication. The work base of Government Public Relations is the continuous management of information and communication to gain public understanding and support for Government Programs and Policies (kominfo.go.id).

According to Cutlip \& Center in Ruslan (2010), "The process of four stages or the main steps of implementing PR's activities", as follows: a. Research and Listening (Research-Listening), b. Planning and Decision Making (Planning-Decission) c. Communicating and Implementation (Communication-Action) d. Evaluate (Evaluation). (Harini, 2014). Public Relations Management (PR's) is the process of planning, implementing, and evaluation of communication activities supported by the organization. Likewise with the management of Cyber Public Relations in realizing a positive image of the organization in the public eye, because one of the goals of an organization's Public Relations activities is to form a positive image in the eyes of the public as a whole (Erliansyah, 2017).

Cyber Public Relations or E-PR is a Public Relations initiative that uses the internet as a means of publicity (Julius Onggo 2004). Meanwhile, according to Deena-doejek (2007) in research (Dewi, 2019), Cyber Public Relations is a public relations activity carried out through cyberspace or cyberspace or known as the internet which is the application of ICT (Information and Communication Technologies) devices to PR needs. According to research by Inez Gabrina and Suharyanti (2014) to be able to achieve success in conducting online public relations practices, there are five basic elements of online public relations that must be considered by public relations practitioners. These elements, as described by Phillips \& Young (2009) are transparency, porosity, the internet as an agent, richness in content, and reach. Grunig's research in Ardianto (2004) suggests that a very effective Public 
Relations action is carried out through what he has called the two-way symmetrical model. Public Relations here is based on the strategy of using research and communication used to manage conflict and increase strategic public understanding. In plain language, the two-way symmetric model explains that it is better to speak and listen than just talk, and to negotiate with the public rather than try the power to change them (public) In the research of Tahoba (2011) explained that the two-way symmetrical model describes a balanced, reciprocal two-way propaganda communication or campaign. This model uses communication techniques to solve or avoid conflicts and improve public understanding strategically. According to Lattimore and Baskin (2012), the two-way symmetrical model describes the orientation of Public Relations in which the organization and its publics conform to each other. It focuses on using socialist research methods to achieve mutual understanding and twoway communication rather than one-way persuasion.

According to Kriyantono (2008) image is a picture that is in the public's mind about the company. Image is the public's perception of the company regarding its services, product quality, corporate culture, company behavior or the behavior of individuals within the company and others. According to Fitriani's research (2012), it can be understood that image is one of the things that can be called the most important company asset that should continue to be

\section{DISCUSSION}

Implementation of Cyber Public Relations in Strengthening the Image of the National Information and Communication Technology Council (WANTIKNAS), in terms of conveying information to the public, Public Relations WANTIKNAS uses the built and maintained through proper planning.

\section{METHOD}

This research uses a case study method with a qualitative approach. According to Bogdan and Bikien (1982) a case study is a detailed examination of one setting or one subject or one document repository or one particular event. While Yin (1989) provides a more technical limitation with an emphasis on its characteristics.

Primary data collection through indepth interviews, and secondary data through documentation. The research subjects are the Public Relations of the National ICT Council which carries out its functions in digital public relations activities, the Head of the Public Relations Bureau, the Ministry of Communication and Information, and the Chairman of the Indonesian Cloud Computing Association, as well as the Executive Director of WANTIKNAS.

Data analysis techniques (Miles and Hubberman in Sugiyono 2019), include data reduction, data presentation, and conclusion drawing/verification. Through this method, it is hoped that research can focus on problems and be able to explore problems more deeply and be able to be analyzed better, so that researchers get objective data in order to know and describe Cyber Government Public Relations Management in Strengthening Organizational Image in the Public Relations of the National Information and Communication Technology Council (WANTIKNAS).

internet as a tool for publication needs or also called cyber public relations. Media is one of the communication tools used by Public Relations WANTIKNAS in its activities including Instagram, Facebook, YouTube and also the official website wantiknas.go.id. 


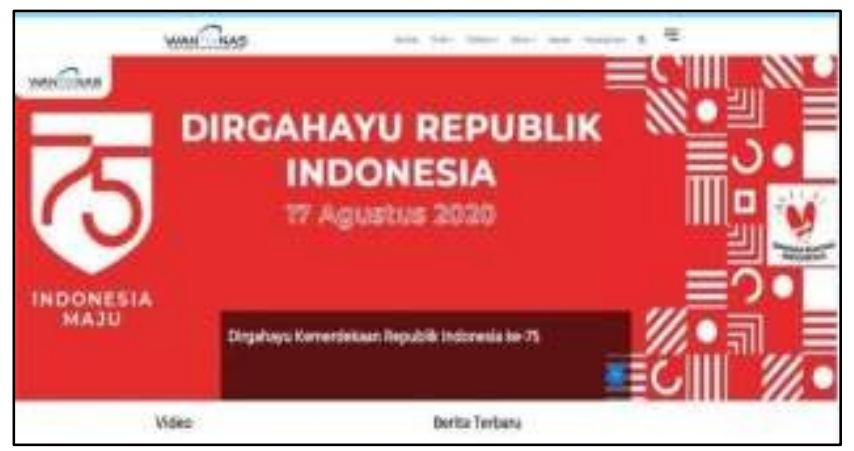

Picture 1. Website of Dewan TIK Nasional

Cyber Public Relations activities of course there are several processes and stages. Public Relations of WANTIKNAS uses the website as the official media to convey information and introduces the profile of WANTIKNAS as the identity of the WANTIKNAS agency. In addition, the official website also contains content related to activities carried out by WANTIKNAS.

The website is also held by the PR team itself in its management, whether it's uploading news, e-Buletins, changing website sliders, to flyers.

related to activities, or replace videos that are directly linked to YouTube WANTIKNAS. Most of the content is managed directly by WANTIKNAS public relations. However, there are some that are not managed by the PR team, namely related to the regulation menu, presentations, studies, there is a separate admin. Researchers observed and observed the Wantiknas website only contained when the activity was running.

Social media has also become a form of media that is now widely used by organizations, including WANTIKNAS. WANTIKNAS has long been active in using social media networks, including Facebook, Instagram, and YouTube. In this case, public relations WANTIKNAS seeks to maximize public relations activities through social media as a means to convey information and also to improve the existence of the organization through social media and also to become a means of two-way information between WANTIKNAS and the public.

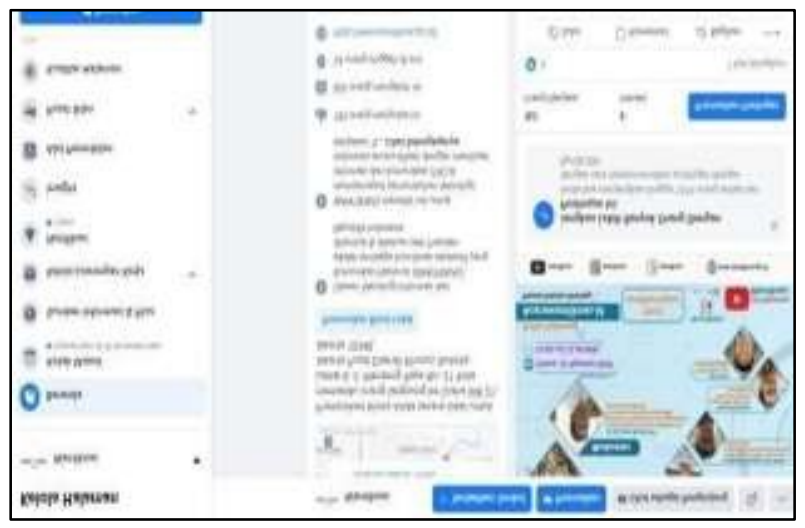

Picture 2. Facebook of Wantiknas

Such as Instagram and Facebook which are now one of the most widely used media in carrying out the function of public relations in conveying information. Instagram and Facebook activities are almost the same, both of which the content is presented is the same. Instagram, Facebook, and YouTube activities themselves are sourced from activities carried out by WANTIKNAS, there is no content that is routinely created every day. 


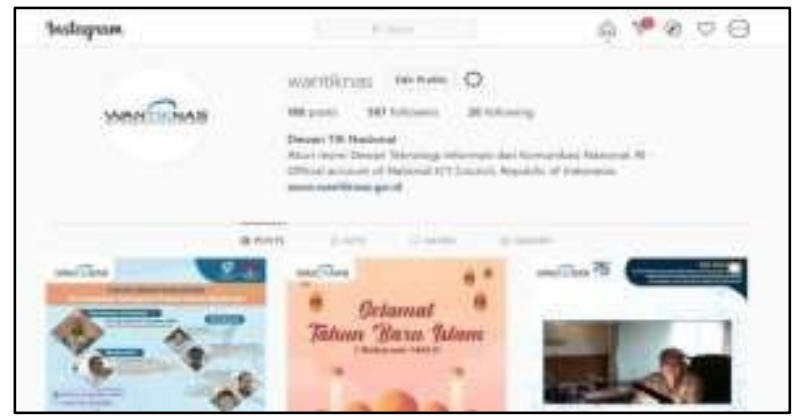

Picture 3. Instagram of Wantiknas

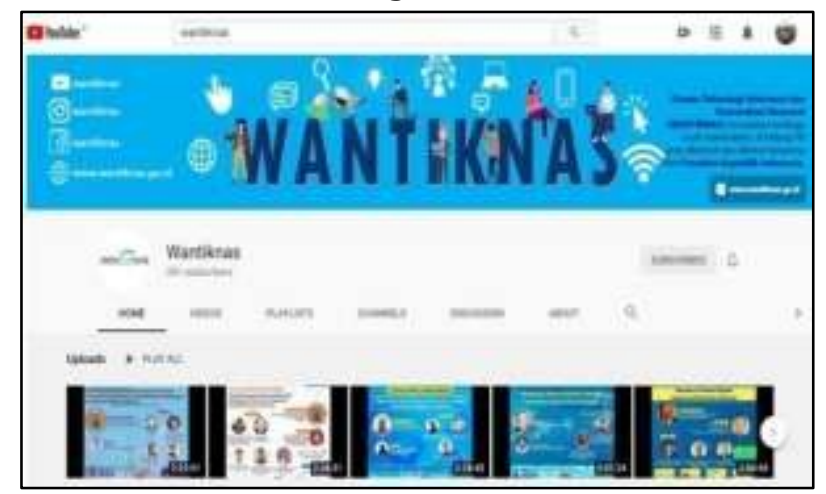

Picture 4. Youtube Wantiknas

Social media has indeed become one of the new alternatives that is quite practical and fast for disseminating information, especially in public relations activities. Besides being fast and not consuming a lot of budget, it is also a medium to encourage the existence of WANTIKNAS through its public relations function so that it is increasingly known to the public. Developments also affect the way WNATIKNAS public relations work by using social media.

Based on the results of research D.S. Moore and J.C. McElroy (2012) states that content on social media with a large number of comments on a post represents the level of success on social media. The number of likes also indicates the content is interesting. Likes and comments have been widely used as a measure of the impact of a publication. Engagement is important because the more engagement you get, the more likely it is that the publication will be accepted by the public.

Engagement is important because it can show a good relationship with the audience and have an impact on audience loyalty.
The lack of engagement that has an impact on audience loyalty to the Wantiknas organization is certainly a concern for how the management carried out by the Wantiknas GPR in the implementation of public relations. Meanwhile, Cyber Public Relations activities should be able to produce what the 3Rs say, namely relations, reputation, and relevance aimed at the company's image (Julius Onggo: 2004).

The process of managing Cyber Government Public Relations Wantiknas based on the observations of researchers to the team that manages public relations activities, generally only uploads content on social media Facebook and Instagram, namely, Wantiknas activity flyers, news linked to the website, holiday memes and uploaded infographics that are inconsistent. every day. While the Cyber Government Public Relations team of Wantiknas has never evaluated its activities either through comments, likes, views or increasing followers due to limited human resources.

Whereas according to Cutlip \& Center in Ruslan (2010), "The process of four stages or the main steps of implementing public 
relations activities, namely research and listening (research-listening), planning and making decisions (planning-decision), communicating and implementing (communication-action). ), and evaluate (evaluation)."

The amount of enthusiasm for public relations activities through digital or Cyber Public Relations certainly affects the way of working or public relations management to be right on target in strengthening the organization's image in the public eye. Having quite a lot of digital platforms in public relations activities, Cyber Public Relations management is a must where one of its triggers is how to manage and strategize digital messages across all platforms used to have an impact on strengthening the image of the organization.

As an institution that is responsible to the president with duties and functions for the acceleration of ICT in Indonesia (Keppres No. 1 of 2014) with a focus aimed at developing digital transformation in Indonesia (Kepmen PPN/Head of Bappenas No. Kep. 45/M/PPN /HK/2020), Wantiknas certainly needs adjustments in managing public relations activities that can communicate digitally or Cyber Public Relations to the public in order to create a good organizational image.

Referring to the data that the researchers observed at the beginning, the researchers concluded that currently Wantiknas has made efforts in managing Cyber Public Relations, as evidenced by the many digital platforms used. Unfortunately, the management has not been maximized as the goal is to encourage the strengthening of the company's image as a non-structural state institution that focuses on the ICT sector with the task of developing digital transformation. In addition, the number of digital platforms used by Wantiknas is not commensurate with the content presented as an effective two-way communication between the organization and its public for mutual understanding. So it can be said that the digital communication strategy used by Wantiknas has not been right on target, because there is still little interaction and public interest in Wantiknas.

This, the researcher concludes, is stated from the data that the researcher wrote at the beginning that there is very little engagement from the public on the Wantiknas social media, even though it has been running for the past one year. This means the image of the Wantiknas organization is still not attached to the wider community, especially in today's digital era. Of course, this is a problem that researchers need to examine more deeply in order to become input for how to manage the Cyber Public Relations Wantiknas which until now has not been maximized in its implementation.

The management of the website is held directly by the Public Relations of WANTIKNAS. But regarding the content, there are indeed some that are filled by other teams as mentioned above regarding regulations, presentations, and studies. Another thing related to the content of the information submitted also contains a description of various activities that have been carried out or will be carried out. In addition, social media activities also follow existing activity patterns, only adding if there are big holidays or government information that needs to be published on WANTIKNAS social media. The findings from several sources also show that the cyber activity of WANTIKNAS Public Relations is still not optimal, in other words, it only exists with various social media, namely Instagram, Facebook, and YouTube. Several findings related to the obstacles faced in its implementation are the lack of human resources who manage cyber public relations, public relations budgets, to the public relations management of WANTIKNAS. Based on these data, it becomes the material for researchers in the 
discussion which will formulate answers to various existing problems. Then these materials also become the basis for providing appropriate recommendations so that the Cyber Government Public Relations Management of WANTIKNAS can be even more optimal and able to provide reinforcement to the image of WANTIKNAS as an institution that has the task of developing ICT or digital transformation.

\section{Discussion}

Public relations governance in a government becomes a management system that can encourage and improve the success of government programs/policies that are sourced from public trust and mutual understanding between the two to achieve common goals. This has also been regulated in the Menpan/RB Regulation No. 30 of 2011 concerning general guidelines for public relations governance, including carrying out reciprocal communication between government agencies and the public that is planned to create mutual understanding and achieve goals, in order to obtain mutual benefits, then improve the smooth running of the community. information flow and public accessibility, and enhance a positive image and reputation.

From the results of the research above, researchers have combined the results of research with the formulation of the problem, in which Public Relations WANTIKNAS has not implemented public relations management in public relations activities in general. Public Relations Wantiknas still follows the pattern of existing WANTIKNAS activities/programs as usual. Every activity carried out by WANTIKNAS, such as Focus Group Discussions, internal routine meetings, coordination meetings, to ICT-Talk discussions is a source in the implementation of public relations activities.

Public relations management, which should be a basic reference in public relations activities and is a continuous process, has not yet been implemented. In addition, the role of Public Relations at WANTIKNAS is only as a transmitter of information to the community and its own institutions as a support team to publish various WANTIKNAS activities. Whereas regarding the position of public relations in government institutions, Cutlip and Center (1994) said that ideally public relations is intended to be in the core staff, directly under the leadership(decision makers) or top managers to be more capable in carrying out their duties. This means that with this position, public relations WANTIKNAS can know and understand directly the background of a decision taken by the leadership, know the direction of the organization and assist in achieving the success of the organization's goals. In this case, Public Relations WANTIKNAS directly receive information to be submitted to the public. Ideally WANTIKNAS public relations are involved in the decision-making process or various activities that are programs or policies of WANTIKNAS, so that public relations functions as a direct channel from WANTIKNAS which will later be packaged into Cyber Public Relations and delivered to the public. Apart from internal WANTIKNAS, public relations is also able to accommodate voices or responses from the public or the wider community regarding the activities taken by WANTIKNAS.

Analysis of the public relations management process carried out by WANTIKNAS which has not yet been implemented, then the results of this study if applied in the correlation of the components of public relations management and the process of the main stages or steps in the implementation of public relations activities from Cutlip \& Center, are: First, Research and listening (Research- Listening)

At this stage according to Cutlip, Center and Broom (2009), the research process is divided into two methods, namely, 
informal or exploration and formal methods. Based on the research results from the data that the researcher has analyzed, WANTIKNAS can carry out two initial methods in research or define what is being carried out by WANTIKNAS. Public Relations WANTIKNAS can use informal methods with personal communication such as interviewing resource persons related to the interests of WANTIKNAS, Focus Group Discussion, searching for data through online media, and field reports. Public Relations of WANTIKNAS can observe the opinions, attitudes, of those with an interest in several WANTIKNAS policies. While the formal method, Public Relations WANTIKNAS can analyze the data that has been obtained which is then re-evaluated some facts from the information by re-identifying what policies are of interest, later a decision will be taken relating to the interests of WANTIKNAS.

Two, Planning and Decision Making (Planning-Decision) In planning activities, WANTIKNAS can take several strategic steps to establish the WANTIKNAS work program or systematic plan that is in line with the interests of achieving the goals of WANTIKNAS every year. Then a sustainable strategy is also needed or it can be said that a comprehensive strategy will become the WANTIKNAS standard that can characterize decision patterns that are able to adapt to opportunities or threats from WANTIKNAS. This standard becomes a reference or benchmark in the implementation of cyber public relations activities in the future.

At this stage, the strategic planning of WANTIKNAS begins with an objective decision on the policies of interest. Then Public Relations WANTIKNAS can determine the target audience that will be targeted by WANTIKNAS, describe the program or policy implemented and why the policy applies, adjust the budget and schedule. In addition, Public Relations WANTIKNAS can identify action and communication strategies. How often will it be communicated to the public, how the content will be presented, what channels will be used by Public Relations WANTIKNAS and in planning also include how the SWOT analysis is carried out. In this case, through the official website channel wantiknas.go.id, social media includes Instagram, Facebook, and YouTube. Here it can be mapped which content is the website, Instagram, Facebook, and YouTube and how the schedule can be implemented which can then be implemented in digital public relations activities called cyber public relations.

Three, Communication and Implementation (Communication-Action) According to Sam Black (Effendy, 2006) government public relations have the task of regularly disseminating information about planning policies and the results that have been achieved, explaining and educating about legislation, regulations and matters relating to the lives of the people themselves. With regard to the above public relations duties, WANTIKNAS public relations can implement the plans that have been prepared by communicating them to the public.

Public Relations of Wantiknas, can disseminate information that has been agreed upon by the leadership to the public through social media and the Wantiknas website appropriately with a two-way communication model. This two-way communication can be more interactive with the community which can then be called using the two-way symmetrical communication model of communication (Grunig-1992).

The purpose of this model is to create two-way communication by creating mutual understanding between WANTIKNAS and the public. According to the researchers' observations, Public Relations WANTIKNAS still uses a one-way communication model, which is only to convey information to the public. Meanwhile, in the general guidelines 
for public relations governance, Menpan/RB Regulation Number 30 of 2011 one of them is to carry out reciprocal communication between government agencies and the public that is planned to create mutual understanding and achieve goals for mutual benefit. So the researcher argues that the two-way symmetrical communication model can be implemented in public relations communication activities, especially in the implementation of cyber public relations.

Implementation of public relations WANTIKNAS at this stage can distribute every agreement that has an interest in this matter through the digital platform used by WANTIKNAS. In this technological era, WANTIKNAS must be more creative and innovative in packaging information, there are many methods ranging from visuals, audio, to various infographics that can be presented in cyber public relations. In addition, from the results of the research above, the researcher views that leadership is very closely related to the success of public relations activities.

Based on data in the field, it is known that the leadership of WANTIKNAS has a considerable impact on public relations activities aimed at the existence of WANTIKNAS. This strategy can be carried out in the implementation of two-way communication with the commitment of leadership at the policy level (at least at the executive director level who then receives input, identifies, and reviews the cyber management of WANTIKNAS Public Relations), of course, through this close commitment, it makes it easier to formulate internal policies management of cyber Public Relations and consistency in its implementation.

In practice, this is very crucial and important, because with the support, policies, and supervision of WANTIKNAS on public relations, it is very important in the success of WANTIKNAS's cyber Public
Relations and strengthening the image of WANTIKNAS as an institution that has a vision and mission of developing ICT or digital transformation. Four, To Evaluate (Evaluation) At this final stage, namely the evaluation of all cyber activities of WANTIKNAS Public Relations, starting from the effectiveness, the planned strategy, and also the communication style delivered. In this case, WANTIKNAS needs to set standards or the existence of measuring tools that have been previously set in planning, so that in evaluating each activity, it can be directed and structured what are the weaknesses and strengths in its implementation.

WANTIKNAS also needs to assess in quantitative and qualitative form each work program that has been implemented. Such as how the public response during carrying out these activities, how much the increase in followers, viewers, to those who access all WANTIKNAS channels. This becomes important in the evaluation stage to encourage future improvements. That way it can be mapped into several parts in the evaluation, including what are the results of what has been implemented, the communication outputs which include public participation and also receiving public information.

Although the implementation of communication management and public relations institutions has not been implemented properly. Humas Wantiknas doesn't limit the existence of information that must be published. Various Public Relations cyber platforms are well utilized by Public Relations WANTIKNAS in managing information, starting from the Website, Instagram, Facebook, and YouTube. The media is a forum for delivering information on WANTIKNAS activities to the public. However, unfortunately cyber Public Relations activities have not been managed properly, even based on data in the field it has not been used optimally for public 
relations activities. This is because digital public relations patterns are based on existing activities, namely following the internal activities of WANTIKNAS itself.

Cyber Public Relations activities are more about making news after the activity takes place, then uploading it on the official website, and photo news on social media networks Instagram and Facebook which are then linked to website links so that they can be read in full, the aim is to attract readers to open the website. In addition, YouTube is also used when there are activities that are open by doing live broadcasts. From the findings above, public relations are increasingly using the internet in their activities, although it is not yet optimal.

This is the same as the theory from John December (1997) in Thurlow (2004) regarding Computer Mediated Communications, that the process of human communication through computers, involves a person, is located in a certain context, and is involved in the process of forming media for various purposes. With several media platforms used by public relations, WANTIKNAS should be able to give rise to what Julius Onggo (2004) said, namely the existence of relationships, namely being able to interact with others.

Various target audiences to build relationships and corporate image. Reputation, which is the most important asset in a business, cyber Public Relations is an art in building an online reputation on an ongoing basis. Relevance, which is to make online Public Relations initiative activities relevant to corporate public targets. However, in reality it has not achieved these three things. Cyber Public Relations activities that are not yet optimal have many obstacles, such as at the beginning the researcher said that WANTIKNAS has not implemented management which has an impact on cyber Public Relations activities that have not been optimal. Then the researcher views that the management of cyber Public Relations needs qualified and sufficient resources in its implementation, with many digital platforms used in public relations activities, WANTIKNAS needs an organized cyber Public Relations team so that they can help formulate related policies which will be informed. through social media. If these resources have been managed properly, then the relevant leaders need to participate in monitoring and evaluating these public relations activities, in order to encourage an increase in wellmanaged cyber Public Relations activities to optimize public communication that is increasingly interactive.

In addition, researchers also see that the need for optimizing cyber Public Relations activities aimed at the existence and image of WANTIKNAS is increasingly known to the public. The effectiveness of digital public relations activities is considered influential in the management of the WANTIKNAS organization. Moreover, based on the results of extracting interview data and direct observation, WANTIKNAS is a government institution that has a strategic role in the current era, namely policies related to ICT or digital transformation. In some of the information the researchers got, there was a lot of material that could be social media content, be it Instagram, Facebook, to video content for YouTube. As the researcher mentioned at the beginning, this leadership commitment is the key in managing cyber Public Relations which has an impact on the existence of WANTIKNAS. If the material is sufficient, leadership commitment, management, sufficient resources, it's time to improve public communication through interactive, innovative, and creative content through various visuals, audio, infographics, to interesting writings oriented to public needs that are aligned with WANTIKNAS internal policies. So that the application of the twoway symmetrical communication public 
relations model can be carried out in order to obtain a sense of mutual understanding between WANTIKNAS and the public.

\section{CONCLUSION}

As one of the government agencies that has the task of developing ICT, the National Information and Communication Technology Council (WANTIKNAS) has transformed public relations activities by utilizing Cyber Public Relations consisting of the website wantiknas.go.id, as well as social media Instagram, Facebook, and YouTube. However, its implementation has not been optimal because WANTIKNAS has not implemented public relations communication management specifically in public relations activities, this is management. In addition, the role and function support team in the delivery of information to the public, constrained by limited human resources in its of public relations in WANTIKNAS is also as a so that public relations has not been placed as a position that has a strategic role.

\section{REFERENCES}

Andrew F. Wood \& Matthew.J. Smith (2005), Online Communication: Linking Technology, Identity and Culture. New jersey : Laurence Erlbaum Associates

Ardianto, Elvinaro (2004), Mediator, Vol.5 No. 22004

Atikah. (2019). "Implementasi Cyber Public Relations Dalam Meningkatkan Citra Positif Perusahaan PT Pln (Persero) Aceh." Universitas Islam Negeri ArRaniry Banda Aceh.

Bogdan. R.C and Biklen S.K (1982). Qualitative Research For Education : An Introduction to Theory and Methods, Boston : Allyn and Bacon. Inc

Cutlip M, Scoot, Allen H. Center, Glen M. Broom. (2009). Effective Public Relations. Yakarta: Kencana.

Dewan Teknologi Informasi dan Komunikasi Nasional. (2020). Profil. Retrieved from http://www.wantiknas.go.id/id/profi l/pendahuluan

Effendy, Onong Uchjana. (2006). Humas Suatu Studi Komunikasi. Bandung: PT. Remaja Rosdakarya.

Erliansyah, Beni. (2017). "Manajemen Pengelolaan Cyber Public Relations Dalam Mewujudkan Good Governance Pemerintah Kota Payakumbuh." Jom Fisip. Vol.4 No.2 Oktober/ 2017, hal. 3.

Gabrina dan Suharyanti (2013-2014). "Analisis Strategi Cyber Public Relations PT. Pertamina (Persero) Untuk Sosialsiasi Penyesuaian Harga LPG 12KG." Journal Communication Spectrum, Vol.3 No.2 Agustus 2013 Januari 2014. Program Studi Ilmu Komunikasi Universitas Bakrie. Hal. 174-191.

Guide to Developing an Online Strategy in the World of Social Media, Second Edition, London and Philadelphia.

Harini, Ira Nur. (2014). Manajemen Hubungan Masyarakat Dalam Upaya Peningkatan Pencitraan Sekolah (Studi Kasus di SMP AL Hikmah Surabaya). Jurnal Inspirasi Manajemen Pendidikan, 4(4), 8-20.

Kementerian Komunikasi dan Informatika. (2006). Lingkup Program Government Public Relation. Retrieved from https://www.kominfo.go.id/content/ detail/6 857/lingkup-program government-publicrelations/0/pp_gpr

Kriyantono, Rachmat (2008), Teknik Riset Komunikasi, Jakarta: Kencana

Lattimore, Baskin, Heiman, Toth. (2012). Public Relations: The Profession and The Practice, Fourth Edition. New York: The McGraw-Hill Companies.

Onggo, Bob J. (2004). Cyber Public Relations. Jakarta: PT. Elex Media Kompetindo.

Phillips, David and Philip Young. (2009). Online Public Relations a Practical.

Robert, K. Yin. (1989) Case Study research Design and Methods (Washington : Cosmos Corporation) 
Rosady Ruslan, (2013). Manajemen Public Relations\& Media Komunikasi. Jakarta: PT.Raja Grafindo Persada.

Sekretariat Kabinet. (2015). Presiden Jokowi Tandatangani Inpres No. 9/2015 Tentang Pengelolaan Komunikasi Publik. Retrieved from https://setkab.go.id/presidenjokowi- tandatangani-inpres-no92015- tentang-pengelolaankomunikasi- publik/ diakses pada 4 Agustus 2020.

Sugiyono (2019), Metode Penelitian Kuantitatif, Kualitatif dan $R \& D$, Penerbit: Alfabeta
Susanto, Utamidewi, Muhamad, Syamsuri. (2019). "Implementasi Cyber Public RelationsUniversitas Singaperbangsa Karawang Pada Persaingan Era Digital." Program Studi Ilmu Komunikasi, Universitas Singaperbangsa Karawang, Jurnal Muara Ilmu Sosial, Humaniora, dan Seni. Vol. 3 No.1, April 2019: hlm 2002010.

Thurlow, Chrispin., Lengel, Laura., Tomic, Alice. (2004). Computer Mediated Communication: Social Intraction and The Internet. London: Sage Publication. 